\title{
PENERAPAN MODEL PEMBELAJARAN KOOPERATIF TIPE THINK PAIR SHARE UNTUK MENINGKATKAN HASIL BELAJAR GEOGRAFI
}

\author{
PRIYONO \\ SMA Negeri 1 Karangdowo \\ e-mail: priyonospd589@gmail.com
}

\begin{abstract}
ABSTRAK
Tujuan dari Penelitian ini untuk meningkatkan hasil belajar geografi dengan penerapan model pembelajaran kooperatif tipe Think Pair Share di kelas XII IPS4 SMA N 1 Karangdowo Klaten tahun pelajaran 2019/2020. Penelitian ini merupakan penelitian tindakan kelas (Classroom Action Research) yang terdiri dari dua siklus dan tiap siklus terdiri dari 4 tahap yaitu perencanaan, pelaksanaan, pengamatan dan refleksi. Subyek penelitian adalah siswa kelas XII IPS4 di SMA N 1 Karangdowo tahun pelajaran 2019/2020 yang berjumlah 34 orang. Teknik pengumpulkan data meliputi observasi, tes hasil belajar dan dokumentasi. Analisis data yang digunakan dalam penelitian ini terdiri dari reduksi data, penyajian data, penarikan kesimpulan atau verifikasi. Teknik analisis data skor hasil belajar menggunakan analisis kuantitatif dengan menggunakan penilaian aspek kognitif, psikomotorik dan penilaian aspek afektif. Hasil penelitian penerapan model pembelajaran kooperatif tipe Think Pair Share adalah sebagai berikut: rata-rata skor hasil belajar siswa pada saat pratindakan sebesar 68 meningkat sebanyak 5\% menjadi 73 pada siklus I, dan lebih meningkat pada siklus II yakni 7\% dengan nilai ratarata 80. Selain itu, tingkat ketuntasan belajar Geografi meningkat yang awalnya pada pratindakan hanya 47\% (16 siswa) yang memenuhi KKM, pada siklus I menjadi 79\% (27 siswa) dan siklus II meningkat menjadi 94\% (32 siswa). Berdasarkan hasil penelitian dapat disimpulkan bahwa penerapan metode pembelajaran kooperatif tipe Think Pair Share dapat meningkatkan hasil belajar geografi pada siswa kelas XII IPS4 SMA N 1 Karangdowo, pada tahun pelajaran 2019/2020.
\end{abstract}

Kata kunci: Metode Pembelajaran Kooperatif, Think Pair Share, Hasil belajar

\section{ABSTRACT}

The purpose of this study is to improve geography learning outcomes by applying the Think Pair Share type cooperative learning model in class XII IPS4 SMA N 1 Karangdowo Klaten for the 2019/2020 school year. This research is a classroom action research (Classroom Action Research) which consists of two cycles and each cycle consists of 4 stages, namely planning, implementation, observation and reflection. The research subjects were students of class XII IPS4 at SMA N 1 Karangdowo in the 2019/2020 school year, totaling 34 people. Data collection techniques include observation, learning outcomes tests and documentation. The data analysis used in this study consisted of data reduction, data presentation, conclusion drawing or verification. The data analysis technique of learning outcome scores uses quantitative analysis by using assessments of cognitive, psychomotor and affective aspects of assessment. The results of the research on the application of the Think Pair Share cooperative learning model are as follows: the average score of student learning outcomes at the time of pre-action was 68 , which increased by $5 \%$ to 73 in the first cycle, and further increased in the second cycle, namely $7 \%$ with an average value. 80. In addition, the level of completeness in learning Geography increased, which initially only $47 \%$ (16 students) met the KKM, in the first cycle it became $79 \%$ (27 students) and the second cycle increased to 94\% (32 students). Based on the results of the study, it can be concluded that the application of the Think Pair Share type of cooperative learning method can improve geography learning outcomes for students of class XII IPS4 SMA N 1 Karangdowo, in the 2019/2020 school year.

Keywords: Cooperative Learning Method, Think Pair Share, Learning Outcomes 


\section{PENDAHULUAN}

Dalam UU No.20 tahun 2003 tentang Sisdiknas di atas dijelaskan bahwa pendidikan memerlukan suasana balajar dan proses pembelajaran. Belajar dapat diartikan sebagai suatu perubahan tingkah laku akibat dari diperolehnya pengalaman melalui interaksi dengan lingkungan. Lingkungan belajar individu meliputi lingkungan keluarga, sekolah dan masyarakat dimana ketiganya saling berhubungan.

Berdasarkan hasil pengamatan proses kegiatan belajar mengajar di kelas XII IPS 4 SMA N 1 Karangdowo Tahun Pelajaran 2019/2020, metode ceramah (konvensional) yang diterapkan guru menjadikan siswa bosan dan mengantuk, sehingga tidak berkonsentrasi dalam proses pembelajaran. Terlebih lagi siswa yang aktif tidak menyeluruh. Hal ini menyebabkan siswa sulit memahami materi yang disampaikan, dan ketercapaian hasil belajar yang diperoleh kurang maksimal.Hasil ulangan harian terlihat dari 34 siswa, (54\%) 18 siswa masih mendapat nilai dibawah batas kriteria ketuntasan minimal (KKM), (30\%) 10 siswa memenuhi KKM akan tetapi dengan nilai mendekati nilai ketuntasan dan (16\%) 6 siswa lulus KKM dengan nilai baik. Nilai KKM SMA N 1 Karangdowo Kabupaten Klaten mata pelajaran Geografi yaitu 70. Kegiatan belajar mengajar yang terpusat kepada guru terlebih tanpa menggunakan media pembelajaran, membuat siswa pasif, terkesan monoton, dan kurangnya interaksi antarsiswa sehingga kurang mengeksplore kemampuan siswa, kemandirian serta rasa tanggungjawab siswa untuk mempu memecahkan setiap permasalahan.

Sudjana (2016:22) menyatakan hasil belajar siswa adalah kemampuan kemampuan yang dimiliki siswa setelah siswa menerima pengalaman belajarnya.Kemampuan siswa mencakup kemampuan di bidang kognitif, afektif, dan psikomotor. Hal-hal yang seharusnya dicapai dalam proses belajar sebagai hasil belajar, yaitu meliputi pengetahuan dan pemahaman tentang konsep, kemampuan menjabarkan dan menarik kesimpulan serta menilai kemanfaatan suatu konsep, menyenangi dan memberi respon positif terhadap sesuatu yang dipelajari, dan diperoleh kecakapan untuk melakukan suatu kegiatan tertentu. Hasil belajar menurut Sumiati dan Asra (2008: 41) diperoleh melalui pengalaman melakukan suatu kegiatan yang akan menuntun pada suatu pemahaman.Menurut Suprijono (2010: 5) hasil belajar adalah pola-pola perbuatan, nilai-nilai, pengertian-pengertian, sikap-sikap, apresiasi dan keterampilan sehingga Hasil belajar adalah kemampuan-kemampuan yang dimiliki siswa setelah ia memperoleh pengalaman belajarnya. Sistem pendidikan nasional menggunakan klasifikasi hasil belajar dari Bloom (1956) sebagai rumusan tujuan pendidikan. Bloom secara garis besar membaginya menjadi tiga ranah yakni ranah kognitif, ranah afektif, dan ranah psikomotor

Model pembelajaran kooperatif merupakan salah satu metode yang dapat digunakan guru untuk menciptakan pembelajaran yang efektif. Dalam pembelajaran kooperatif, guru berperan sebagai fasilitator yang berfungsi sebagai jembatan penghubung ke arah pemahaman yang lebih tinggi, dengan catatan siswa sendiri. Guru tidak hanya memberikan pengetahuan pada siswa, tetapi harus membangun dalam pikirannya juga. Siswa mempunyai kesempatan untuk mendapatkan pengetahuan langsung dalam menerapkan ide-ide mereka sendiri.

Menurut Eggan Kauchak (Trianto, 2011:42) pembelajaran kooperatif adalah sebuah kelompok strategi pengajaran yang melibatkan siswa bekerja secara berkolaborasi untuk mencapai tujuan bersama. Pembelajaran kooperatif adalah model pembelajaran yang mengutamakan kerja sama untuk mencapai tujuan pembelajaran. Cooperative learning merupakan bentuk pembelajaran dengan cara siswa belajar dan bekerja dalam kelompokkelompok kecil secara kolaboratif.

Abdulhak mengemukakan pembelajaran kooperatif dilakukan melalui sharing proses antara peserta didik, sehingga dapat mewujudkan pemahaman bersama antara peserta didik itu sendiri. sedangkan Tom V. Savage mengemukakan bahwa "Cooperative learning merupakan suatu pendekatan yang menekankan kerja sama dalam kelompok." ( Aunurahman, 2012 :1920).

Menurut Nurhayati, pembelajaran kooperatif adalah Strategi pembelajaran yang melibatkan partisipasi siswa dalam suatu kelompok kecil untuk saling berinteraksi Dalam 
sistem belajar yang kooperatif, siswa bekerjasama dengan anggota lainnya. berdasarkan uraian diatas, dapat dipahami bahwa dalam pembelajaran kooperatif siswa memiliki dua tanggung jawab, yaitu belajar untuk dirinya sendiri, dan membantu sesama anggota untuk belajar. (Abdul majid, 2013: 173)

Dari beberapa definisi tersebut diatas dapat disimpulkan bahwa pembelajaran kooperatif adalah proses terjadinya pembelajaran dengan adanya kesedaran kerja sama antara siswa dan guru serta antar siswa untuk mencapai tujuan. Pembelajaran kooperatif menyumbangkan ide bahwa siswa yang bekerja sama dalam belajar dan bertanggung jawab terhadap teman satu kelompoknya mampu membuat mereka belajar sama baiknya. Dalam hal ini siswa dituntut untuk dapat berinteraksi dengan anggota kelompoknya.

Dasar-dasar model Think, Pair and Share dikenalkan oleh Frank Lyman pada tahun 1985. Pembelajaran TPS ini dirancang untuk mempengaruhi pola interaksi siswa. Model pembelajaran Think Pair Share termasuk salah satu model pembelajaran kooperatif. Model pembelajaran ini mampu berkontribusi dalam proses pembelajaran. Siswa dapat berkomunikasi secara langsung oleh individu lain yang dapat saling memberi informasi dan bertukar pikiran serta mampu berlatih untuk mempertahankan pendapatnya jika pendapat itu layak untuk dipertahankan. Think Pair Share memiliki prosedur yang ditetapkan secara eksplisit untuk memberi waktu lebih banyak kepada siswa untuk berfikir, menjawab, dan saling membantu satu sama lain.

Model pembelajaran Think Pair Share ini dalam Strategi Pembelajaran Aktif ( Zaini Hazyam, 2008: 52) juga disebut model pembelajaran The Power of Two (Kekuatan dua kepala). Aktivitas pembelajaran ini digunakan untuk mendorong pembelajaran kooperatif dan memperkuat arti penting serta manfaat sinergi dua orang. Strategi ini mempunyai prinsip bahwa berpikir berdua jauh lebih baik daripada berpikir sendiri.

Dalam tahapan Think, pair, dan share inilah, kecakapan siswa dalam berkomunikasi yang meliputi kecakapan mendengar, berbicara, membaca maupun melukiskan gagasan atau pendapatnya ketika pembelajaran berlangsung akan terlihat. Adanya pemberian masalah dilakukan untuk melihat penguasaan dan pemahaman siswa mengenai materi yang telah dipelajarinya.Langkah-langkah model pembelajaran tersebut apabila dikaji dengan baik, maka akan memberikan peluang kepada siswa untuk mengembangkan kemampuan menerapkan konsep, keterampilan berkomunikasi, dan keterampilan diskusi mengajukan pertanyaan.

Berdasarkan latar belakang masalah tersebut guru perlu mengatasi permasalahan yang ada, salah satu caranya dengan menerapkan model pembelajaran baru yang dapat meningkatkan hasil belajar siswa dan dapat memperbaiki kualitas pembelajaran di kelas. Salah satu model pembelajaran yang dapat digunakan untuk meningkatkan hasil belajar siswa yang diharapkan berimplikasi pada peningkatan prestasi belajar adalah model pembelajaran Think Pair Share. Melalui penerapan model pembelajaran TPS dalam pembelajaran geografi siswa diajak untuk berpikir aktif secara individual atas pertanyaan yang diberikan oleh guru dengan waktu tertentu, kemudian guru menginstruksikan untuk mendiskusikan jawaban dengan berpasangan kemudian dikemukakan didepan kelas. Think yaitu proses berfikir aktif seorang individu. Pair yaitu proses berpasangan, bekerja sama menggabungkan dua jawaban yang berbeda untuk didiskusikan menjadi satu jawaban yang lebih sempurna, dan dengan jawaban kelompok tersebut masing-masing kelompok diberikan kesempatan untuk menyampaikan hasil diskusinya didepan kelas, dan kelompok lain diberi kesempatan untuk menanggapi setiap jawaban yang disajikan per kelompok.

Berdasarkan latar belakang diatas maka rumusan masalah dalam penelitian ini adalah "Apakah model pembelajaran kooperatip Think Pair Share dapat meningkatkan hasil belajar geografi?" Penelitian ini bertujuan untuk meningkatkan hasil belajar geografi.Penerapan model pembelajaran kooperatif tipe think pair share diharapkan dapat meningkatkan hasil belajar geografi. 


\section{METODE PENELITIAN}

Penelitian ini dilakukan di kelas XII IPS 4 SMA N 1 Karangdowo, Klaten. Adapun yang menjadi subyek penelitian ini adalah siswa kelas XII IPS4 dengan jumlah siswa 34 siswa yaitu laki-laki sebanyak 10 siswa, perempuan 24 siswa.Penelitian dilaksanakan pada semester gasal (1) tahun pelajaran 2019/2020. Pelaksanaan penelitian ini dilakukan secara bertahap dari bulan Juli-September 2019. Subjek penelitian ini adalah siswa kelas XII IPS4 dengan jumlah 34 siswa terdiri dari 10 siswa laki-laki dan 24 siswa perempuan. Pemilihan subjek dalam penelitian ini didasarkan pada pertimbangan bahwa subjek tersebut mempunyai permasalahan yang telah diidentifikasi pada saat observasi pratindakan.Obyek penelitian ini adalah berbagai kegiatan yang terjadi di dalam kelas selama berlangsungnya proses belajar mengajar.

Analisa data menggunakan model analisis Miles dan huberman yang dilakukan dalam tiga alur kegiatan yaitu : Reduksi data, Penyajian data, dan Penarikan kesimpulan dan verifikasi (Suharsimi Arikunto, 2009).Teknik analisa data kuantitatif digunakan untuk menilai hasil belajar siswa. Sesuai dengan jenis data kuantitatif dapat diolah dan dianalisis dengan teknik perhitungan statistika dan matematika. Data kuantitatif berfungsi untuk mengetahui jumlah atau besaran sebuah obyek yang diteliti. Data ini diperoleh dari tes hasil belajar siswa pada saat awal sebelum pembelajaran (pre test) dan tes pada akhir pembelajaran (post test).Indikator yang ingin dicapai dalam penelitian ini adalah peningkatan hasil belajar sosiologi pada kelas XII IPS 4 SMA N 1 Karangdowo, Klaten dengan pembelajaranan kooperatif tipe Think Pair Share (TPS). Dalam hal ini prosedur penelitian tindakan kelas terdiri dari empat tahapan, yaitu: Perencanaan,pelaksanaan,pengamatan dan refleksi.

Secara rinci urutan masing-masing tahap digambarkan dalam bagan sebagai berikut:

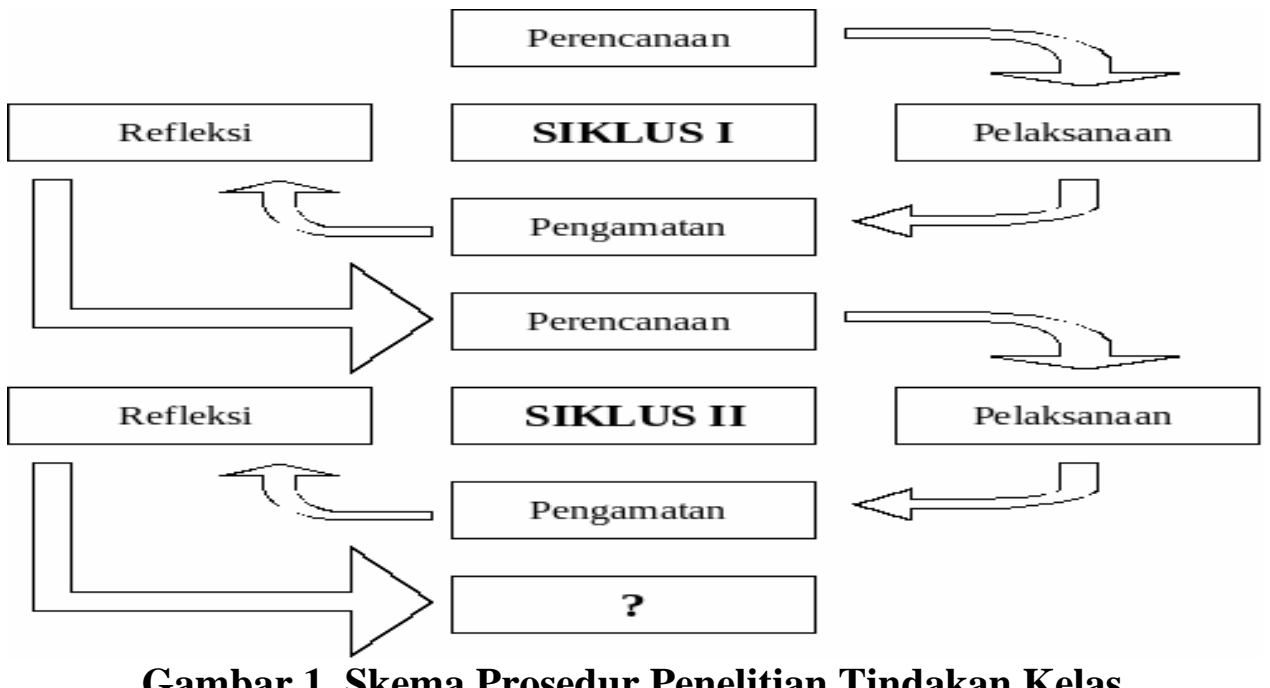

Gambar.1. Skema Prosedur Penelitian Tindakan Kelas

(Suharsimi Arikunto, Suhardjono dan Supardi, 2009:74)

\section{HASIL DAN PEMBAHASAN}

Hasil

Sebelum melakukan penelitian tindakan kelas (PTK) yang bertujuan untuk memperbaiki pembelajaran di kelas, guru terlebih dahulu melakukan pra tindakan untuk mengetahui permasalahan yang ada saat proses pembelajaran dikelas dan memfokuskan suatu masalah yang segera harus diperbaiki. Guru melakukan pratindakan dengan melakukan pengamatan kepada siswa dikelas ketika Kegiatan Belajar Mengajar. Pratindakan di SMA N 1 Karangdowo pada kelas XII IPS 4. Dari data yang diperoleh ketika pengamatan berlangsung, dapat disimpulkan sebagai berikut Hasil Belajar Geografi Rendah.

Dalam pengamatan ketika proses belajar mengajar berlangsung dikelas, ditemukan data bahwa hasil belajar siswa masih dibawah KKM (Kriteria Ketuntasan Minimal) KKM Mata pelajaran Geografi yaitu 70, siswa tidak mau bertanya, meskipun ada pelajaran yang kurang dipahami, tidak mau menjawab pertanyaan guru apabila tidak ditunjuk, kesulitan untuk 
menjawab pertanyaan guru. Terlebih dengan model pembelajaran yang digunakan sebelum tindakan yaitu model konvensional yakni ceramah yang dikombinasi dengan tanya jawab, akan tetapi yang menjawab anak tertentu saja, dan tidak semua anak berani mengungkapkan pendapat maupun jawabannya, proses kegiatan belajar mengajar berlangsung satu arah, guru menyampaikan materi sedangkan siswa hanya mendengarkan, siswa terlihat pasif, dan tidak ada interaksi antar siswa yang membahas mengenai materi pembelajaran. Berikut tabel hasil belajar Geografi pada siswa kelas XII IPS 4 SMA N 1 Karangdowo sebelum tindakan :

Tabel 1. Hasil Belajar Geografi pada Pratindakan Kelas XII IPS 4

\begin{tabular}{|l|l|l|l|l|l|l|l|l|l|}
\hline Nilai & 60 & 64 & 65 & 70 & 72 & 74 & 80 & 82 & 84 \\
\hline Jumlah & 7 & 3 & 8 & 5 & 3 & 2 & 4 & 1 & 1 \\
\hline
\end{tabular}

Berdasarkan data tabel hasil belajar siswa kelas XII IPS, dapat disimpulkan bahwa siswa yang mencapai batas tuntas 47\% (16 siswa) sedangkan 53\% (18 siswa) lainnya dinyatakan belum tuntas, dengan perolehan nilai rata-rata siswa yaitu 68 nilai terendah 60, dan nilai tertinggi 84 dengan nilai batas ketuntasan minimal 70. Hal ini menggambarkan bahwa hasil belajar siswa kelas XII IPS 4 masih tergolong rendah.

\section{Deskripsi Siklus I}

Penerapan model pembelajaran kooperatif tipe Think Pair Share (TPS) pada siklus I sebagai berikut:

Dengan metode think pair share ini ternyata mampu memotivasi siswa untuk aktif dan diskusi dapat berjalan dengan baik. Pada pertemuan kedua dalam siklus I ini sudah mulai terjadi peningkatan dalam pembelajaran terlihat dari setiap kelompok mempersentasikan hasil diskusi terdapat siswa yang berani bertanya. Setelah diskusi kelompok, terdapat peningkatan pada nilai psikomotorik maupun penilaian afektif siswa, yang mencakup siswa mampu memposisikan diri pada setiap kelompoknya, muncul kesadaran dari siswa untuk menyelesaikan setiap persoalan, dan mampu mengidentifikasi suatu permasalahan kedalam setiap sub bab pembagaian wilayah serta aspek-aspek dalam penataan ruang. sedangkan dari segi memaparkan atau mendemonstrasikan hasil diskusi setiap kelompok masih belum mengalami peningkatan yang signifikan. Berikut tabel penilaian psikomotorik maupun afektif siswa dalam mata pelajaran Geografi dengan materi pokok wilayah dan tata ruang dalam kegiatan diskusi kelompok pada siklus I Pertemuan Ke-2 kelas XII IPS 4 SMA N 1 Karangdowo:

Tabel 2. Penliaian Psikomotorik dan Afektif pada Siklus I

\begin{tabular}{lcc}
\hline \multicolumn{1}{c}{ Kategori } & Jumlah Siswa & Presentase \\
\hline Baik Sekali (BS) & 4 & $86-100$ \\
Baik (B ) & 15 & $71-85$ \\
Cukup (C) & 10 & $56-70$ \\
Kurang (D) & 5 & $\leq 55$ \\
\hline
\end{tabular}

Pertemuan Ke-3 (Ulangan Evaluasi Pembelajaran Siklus I)

Berdasarkan hasil belajar pada ulangan evaluasi pembelajaran Geografi kelas XII IPS 4 SMA N 1 Karangdowo dapat disimpulkan bahwa interval nilai siswa berkisar antara 60-90, dengan nilai terendah 68, nilai rata-rata klasikal 73, dan nilai tertinggi 85. Siswa dikatakan tuntas dalam belajarnya apabila hasil belajar yang diperoleh diatas nilai Kriteria Ketuntasan Minimal (KKM). KKM mata pelajaran Geografi pada SMA N 1 Karangdowo yaitu 70. Sedangkan ketuntasan klasikal 79\% atau sebanyak 27 siswa, sedangkan nilai siswa yang dibawah Kriteria ketuntasan Minimal sebanyak 21\% atau 7 siswa. 


\section{Deskripsi Siklus II}

Penerapan model pembelajaran kooperatif tipe Think Pair Share (TPS) pada siklus II sebagai berikut:

Setelah diskusi kelompok pada pertemuan ke-2 terdapat peningkatan nilai psikomotorik maupun afektif siswa, yang mencakup siswa mampu mengklasifikasikan setiap persolan, siswa memiliki kesadaran untuk aktif berpartisipasi dalam pembelajaran, siswa mampu mengidentifikasi setiap persoalan dan memberikan solusi dari setiap persoalan, siswa lebih bertanggungjawab dalam mengerjakan tugas. Berikut tabel penilaian Psikomotorik maupun afektif siswa dalam mata pelajaran Geografi dengan materi pokok permasalahan dalam penerapan tata ruang wilayah dalam kegiatan diskusi kelompok pada siklus II Pertemuan ke-2 kelas XII IPS 4 SMA N 1 Karangdowo:

Tabel 3. Penilaian Psikomotorik dan Afektif Siklus II

\begin{tabular}{lcc}
\hline \multicolumn{1}{c}{ Kategori } & Jumlah Siswa & Presentase \\
\hline Baik Sekali (BS) & 12 & $86-100$ \\
Baik (B ) & 20 & $71-85$ \\
Cukup (C) & 2 & $56-70$ \\
Kurang (D) & 0 & $\leq 55$ \\
\hline
\end{tabular}

Berdasarkan hasil belajar pada ulangan evaluasi pembelajaran siklus II mata pelajaran Geografi kelas XII IPS 4 SMA N 1 Karangdowo dapat disimpulkan bahwa interval nilai siswa berkisar antara 60-90, dengan nilai terendah 69, nilai rata-rata klasikal 80, dan nilai tertinggi 92. Siswa dikatakan tuntas dalam belajarnya apabila hasil belajar yang diperoleh diatas nilai Kriteria Ketuntasan Minimal (KKM). KKM mata pelajaran Geografi pada SMA N 1 Karangdowo yaitu 70. Sedangkan ketuntasan klasikal 94\% atau sebanyak 32 siswa.

Pembelajaran pada siklus II sudah berjalan semakin baik dari sebelumnya. Pembagian kelompok dan langkah-langkah dalam metode pembelajaran Think Pair Share (TPS) sudah berjalan lebih teratur dari pada siklus I, Interaksi antara guru dengan siswa semakin intensif dan hasil belajar siswa semakin meningkat. Sehingga penelitian dirasa cukup menunjukkan perubahan yang signifikan.

\section{Pembahasan}

Dari hasil observasi dan kegiatan pembelajaran evaluasi setiap siklusnya dapat dilihat perbandingan hasil tindakan siklus I, dan siklus II dengan menggunakan penerapan metode pembelajaran kooperatif tipe Think Pair Share (TPS) dapat meningkatkan hasil belajar siswa pada mata pelajaran Geografi setiap siklusnya. Peningkatan hasil belajar siswa dapat dilihat pada tabel berikut :

\section{Perbandingan Penilaian Psikomotorik dan Afektif}

Tabel 4. Perbandingan Penilaian Psikomotorik dan Afektif pada Mata Pelajaran Geografi Kelas XII IPS 4 Antarsiklus

\begin{tabular}{|c|c|c|c|c|}
\hline \multirow{2}{*}{ Tindakan } & \multicolumn{4}{|c|}{ Kategori } \\
\cline { 2 - 5 } & Baik Sekali (BS) & Baik (B) & Cukup (C) & Kurang (D) \\
\hline Pratindakan & 2 & 10 & 16 & 6 \\
\hline Siklus I & 4 & 15 & 10 & 5 \\
\hline Siklus II & 12 & 20 & 2 & 0 \\
\hline
\end{tabular}

Dari tabel diatas dapat dilihat dalam tiap tindakan jumlah atau frekuensi penilaian psikomotorik dan afektif mengalami peningkatan. Hal ini dapat dilihat dalam proses kegiatan pembelajaran di dalam kelas. Kurangnya partisipasi siswa saat pratindakan adalah sebanyak 6 siswa (17\%), siklus I adalah berkurang menjadi 5 siswa (15\%) dan siklus II tidak terdapat siswa dengan kategori kurang berpartisipasi (0\%). Untuk kategori Cukup berpartisipasi pada 
pratindakan ada sebanyak 16 siswa yang cukup berpartisipasi (47\%), siklus I sebanyak 10 siswa (29\%), dan siklus II hanya 2 siswa dengan kategori cukup (5\%). Sedangkan Kategori Baik dan Sangat Baik meningkat setiap tindakannya, yakni pada pratindakan sebanyak 12 siswa (34\%), siklus I terdapat 19 siswa (56\%), dan pada siklus II sebanyak 32 siswa (94\%).

\section{Perbandingan Hasil Belajar Geografi dilihat dari Penilaian Kognitif}

Dengan penerapan metode pembelajaran Think Pair Share terbukti mampu memperbaiki permasalahan yang ada di kelas dan berdampak pada peningkatan hasil belajar Geografi pada kelas XII IPS 4 SMA N 1 Karangdowo. Peningkatan hasil belajar siswa dapat ditunjukkan dalam tabel berikut :

Tabel 5. Perbandingan Hasil Belajar Siswa di Setiap Tindakan

\begin{tabular}{|l|c|c|c|c|c|}
\hline \multirow{2}{*}{ Tindakan } & \multicolumn{5}{|c|}{ Kategori } \\
\cline { 2 - 6 } & $\begin{array}{c}\text { Nilai } \\
\text { Terendah }\end{array}$ & $\begin{array}{c}\text { Nilai } \\
\text { Tertinggi }\end{array}$ & $\begin{array}{c}\text { Nilai Rata- } \\
\text { Rata }\end{array}$ & Tuntas & $\begin{array}{c}\text { Tidak } \\
\text { Tuntas }\end{array}$ \\
\hline Pratindakan & 60 & 84 & 68 & $47 \%$ & $53 \%$ \\
\hline Siklus I & 68 & 85 & 73 & $79 \%$ & $21 \%$ \\
\hline Siklus II & 69 & 92 & 80 & $94 \%$ & $6 \%$ \\
\hline
\end{tabular}

Dari tabel diatas dapat dilihat terjadi peningkatan yang signifikan terhadap hasil belajar siswa. Berikut ulasan perbandingan nilai rata-rata disetiap tindakan. Saat pratindakan rata-rata siswa hanya mencapai 68 namun disiklus I rata-rata siswa meningkat menjadi 73, sedangkan di siklus II nilai rata-rata lebih meningkat menjadi menjadi 80. Untuk lebih jelasnya dapat dilihat pada gambar berikut :

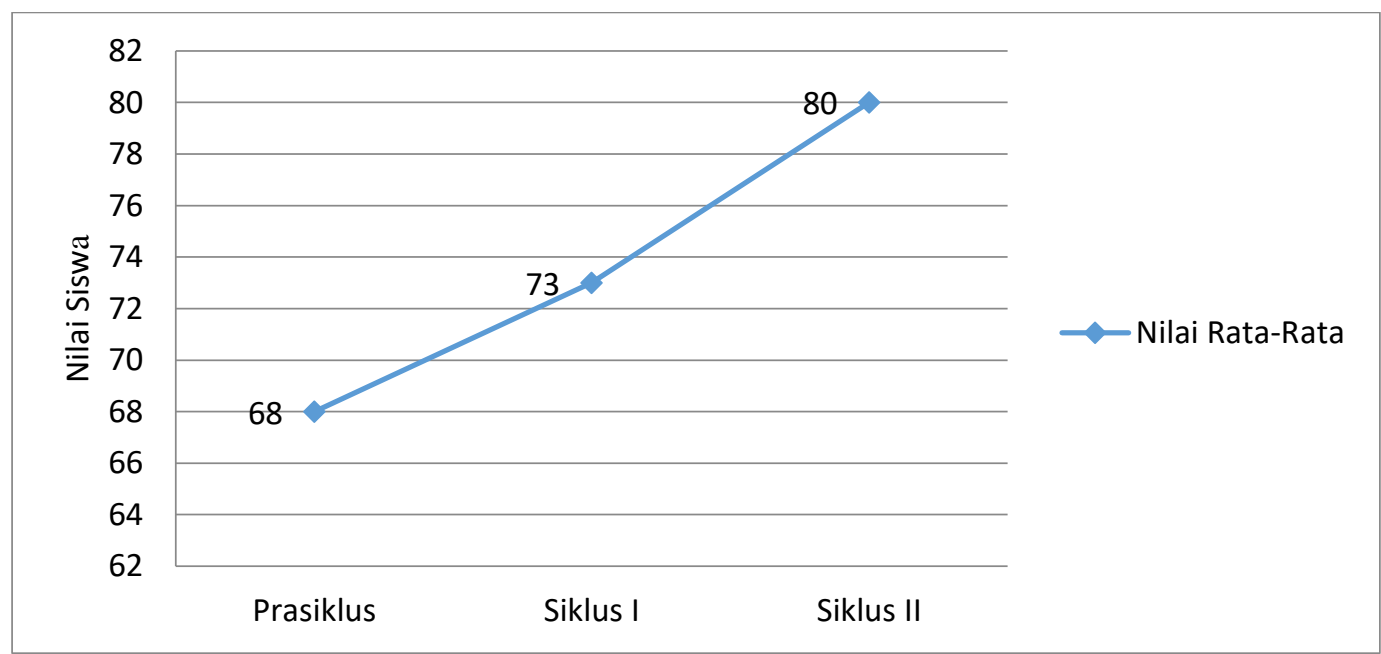

Gambar 2. Grafik Perbandingan Nilai Rata-Rata Setiap Siklus

Selain rata-rata nilai Geografi siswa mengalami peningkatan, persentase siswa yang mengalami ketuntasan dalam belajar Geografi juga meningkat. Dapat dilihat pada tabel berikut adalah perbandingan persentase ketuntasan belajar:

Tabel 5. Ketuntasan Belajar Geografi pada kelas XII IPS 4

\begin{tabular}{cccc}
\hline Kriteria & Pratindakan & Siklus I & Siklus II \\
\hline Tidak Tuntas & $53 \%$ & $21 \%$ & $6 \%$ \\
Tuntas & $47 \%$ & $79 \%$ & $94 \%$ \\
\hline
\end{tabular}

Dari tabel diatas dapat disimpulkan bahwa pada sebelum dilakukannya tindakan sebanyak $53 \%$ siswa tidak tuntas dalam pelajaran Geografi, siklus I adalah 21\%, siklus II sebanyak $6 \%$ tidak tuntas. Sedangkan siswa yang tuntas dalam belajar Geografi pada 
pratindakan $47 \%$ siswa, siklus I adalah 79\%, siklus II meningkat menjadi 94\%. Untuk lebih jelasnya dapat dilihat pada gambar berikut:

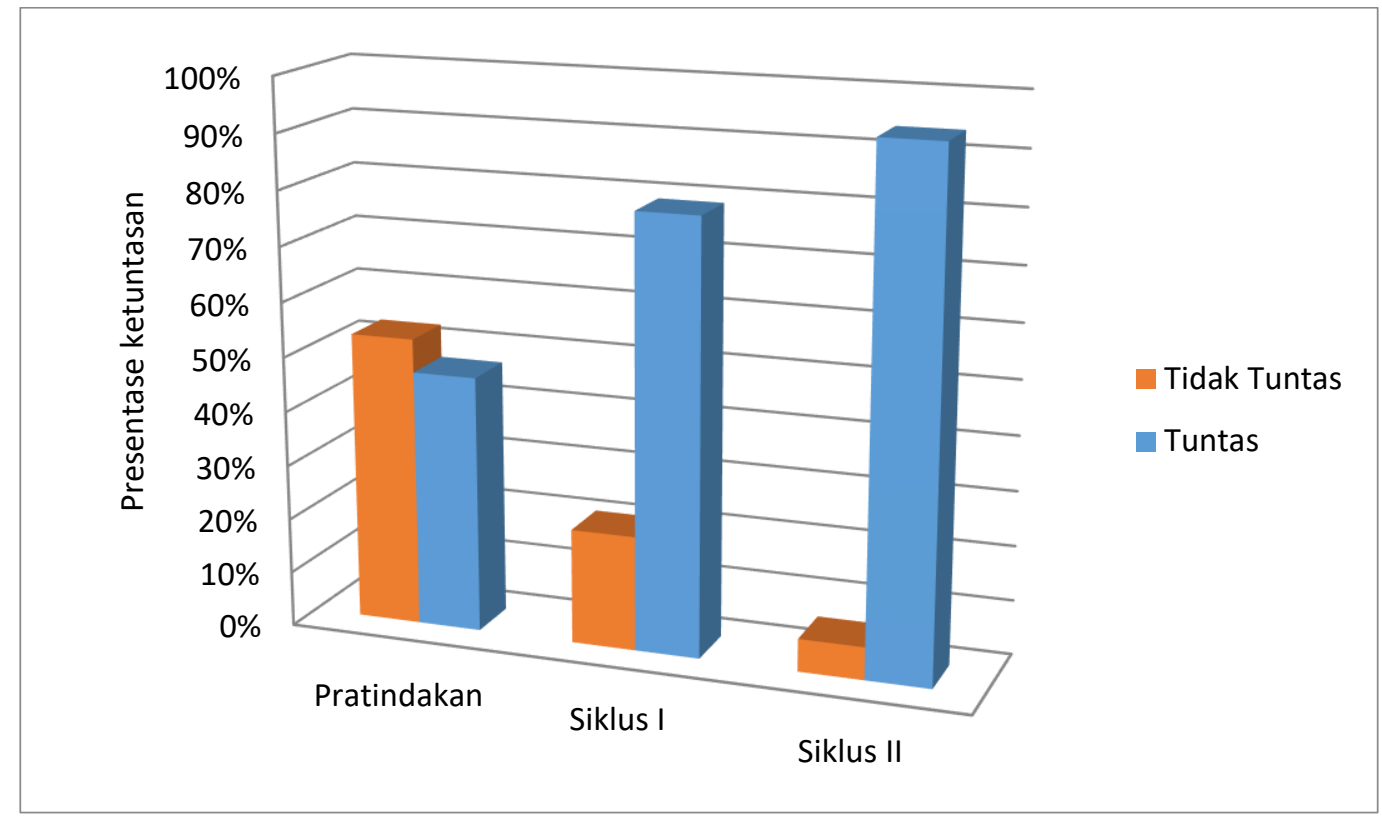

Gambar 3. Perbandingan Presentase Ketuntasan Belajar Geografi Antarsiklus

Berdasarkan temuan hasil penelitian yang telah peneliti lakukan seperti yang peneliti kemukakan diatas, hasil observasi prasiklus, siklus I, dan siklus II penerapan metode pembelajaran kooperatif tipe Think Pair Share (TPS) ini terbukti dapat meningkatkan hasil belajar siswa dalam pembelajaran Geografi. Penelitian ini dilaksanakan dalam dua siklus, dimana setiap siklusnya menggunakan metode pembelajaran yang sama yaitu Think Pair Share (TPS).

\section{KESIMPULAN}

Berdasarkan penelitian tindakan kelas (PTK) pada siswa kelas XII IPS 4 di SMA N 1 Karangdowo tahun pelajaran 2019/2020 yang telah dilaksanakan dalam dua siklus yang didahului pratindakan. Terdiri dari empat tahapan, yaitu perencanaan, pelaksanaan tindakan, observasi atau pengamatan, dan refleksi. Berdasarkan pembahasan dan hasil penelitian maka dapat disimpulkan bahwa penerapan metode pembelajaran kooperatif tipe Think Pair Share (TPS) dapat meningkatkan hasil belajar Geografi pada siswa kelas XII IPS 4 SMA N 1 Karangdowo Tahun Pelajaran 2019/2020, dan mampu memperbaiki permasalahan didalam kelas. Hal ini dapat dilihat terjadi peningkatan rata-rata perolehan nilai hasil belajar geografi dari pratindakan nilai 68 meningkat 5\% menjadi 73 pada siklus I, dan lebih meningkat pada siklus II yakni meningkat $7 \%$ dengan nilai rata-rata 80 . Selain itu, tingkat ketuntasan belajar Geografi meningkat yang awalnya pada pratindakan hanya 47\% (16 siswa) yang memenuhi KKM, pada siklus I menjadi 79\% (27 siswa) dan siklus II meningkat menjadi 94\% (32 siswa).

Penelitian ini memberikan suatu gambaran yang jelas bahwa keberhasilan proses pembelajaran dipengaruhi oleh beberapa faktor. Faktor-faktor tersebut bisa berawal dari guru ketika pembelajaran berlangsung, siswa, media, dan bahkan metode pembelajaran yang diterapkan guru dikelas. Pada dasarnya karakteristik siswa yang unik menjadikan beragamnya permasalahan yang muncul ketika proses pembelajaran. Sehingga sangat penting bagi guru untuk melakukan penelitian tindakan kelas (PTK) sebagai upaya mengidentifikasi permasalahan yang muncul, dan melakukan perbaikan agar tujuan dari pendidikan dapat tercapai secara optimal.

Pengembangan kemampuan guru dalam menyampaikan materi, mengelola kelas, dan metode yang digunakan dalam setiap pembelajaran hendaknya bervariatif agar proses 
pembelajaran lebih inovatif. Salah satunya dengan penerapan metode pembelajaran kooperatif Think Pair Share. Hal ini mampu memacu siswa untuk lebih antusias berpartisipasi dalam kegiatan pembelajaran, dan berimplikasi pada peningkatan hasil belajar siswa, dalam hal ini terjadi peningkatan hasil belajar mata pelajaran Geografi. Sarana maupun prasarana dalam pembelajaran turut andil menjadi faktor penting agar siswa lebih tertarik dalam pembelajaran dan fokus pada materi.

Penelitian Tindakan Kelas ini memberikan deskripsi bahwa dengan penerapan metode kooperatif Think Pair Share mampu meningkatkan hasil belajar Geografi siswa kelas XII IPS 4 di SMA N 1 Karangdowo. Penelitian ini dapat digunakan sebagai upaya perbaikan dan solusi untuk mengatasi permasalahan didalam kelas. Terlebih tahapan-tahapan yang ada dalam metode Think Pair Share mudah diterapkan, proses diskusi menyebabkan siswa lebih mudah berfikir secara berkelompok dibandingkan secara individu, sehingga terjadi pertukaran pemikiran, dan menyamakan persepsi, dan melalui proser berfikir kritis dan inovatif, serta menambah wawasan dalam proses pengerjaan soal. Metode ini cukup efektif diterapkan di kelas dengan karakteristik siswa yang berkarakter unik, dan beragam.

\section{DAFTAR PUSTAKA}

Aqib, Zainal. (2013). Model-model, Media, dan Strategi Pembelajar Kontekstual. Bandung:Yrama Widya.

Arikunto, Suharsimi. (2009). Penelitian Tindakan Kelas. Jakarta:Bumi Aksara.

Aunurrahman. (2010). Belajar dan Pembelajaran. Bandung:Alfabeta.

Khotimah, Nurul.dkk (2016).Buku Siswa Geografi Untuk Kelas XII (Peminatan Ilmu-Ilmu Sosial). Klaten: Cempaka Putih.

Lie, Anita. (2008). Mempraktikkan Cooperative Learning Di Ruang-Ruang Kelas. Jakarta:Grasindo.

Majid, Abdul. (2013). Strategi Pembelajaran. Bandung: Remaja Rosdakarya.

Mulyasa, E. (2012). Praktik Penelitian Tindakan Kelas. Bandung:Remaja Rosdakarya.

Nugroho, Fajar. (2013). Modul Bahan Ajar Geografi (Peminatan Ilmu-Ilmu Sosial) Untuk SMA/MA Kelas XII Semester 1 Jilid 3A.Sukoharjo: Sindunata.

Rusyan, A.Tabrani., Kusdinar, A., \& Arifin, Z. (1989). Pendekatan Dalam Proses Belajar Mengajar. Bandung: Remadja Karya.

Slameto. (2010). Belajar dan Faktor-Faktor yang Mempengaruhi. Jakarta: Rineka Cipta.

Sujana, Nana. (2008). Dasar-Dasar Proses Belajar Mengajar. Bandung:Sinar Baru Algensindo.

Suprijono, Agus. (2010). Cooperative Learning Teori dan aplikasi PAIKEM. Yogyakarta: Pustaka Pelajar. 